\title{
Fantasy Literature and the Misanthrope: A Review Article of New Work by Cottom and Zipes
}

\author{
Terri Ochiagha \\ Complutense University Madrid
}

Follow this and additional works at: https://docs.lib.purdue.edu/clcweb

Part of the Comparative Literature Commons, and the Critical and Cultural Studies Commons

Dedicated to the dissemination of scholarly and professional information, Purdue University Press selects, develops, and distributes quality resources in several key subject areas for which its parent university is famous, including business, technology, health, veterinary medicine, and other selected disciplines in the humanities and sciences.

CLCWeb: Comparative Literature and Culture, the peer-reviewed, full-text, and open-access learned journal in the humanities and social sciences, publishes new scholarship following tenets of the discipline of comparative literature and the field of cultural studies designated as "comparative cultural studies." Publications in the journal are indexed in the Annual Bibliography of English Language and Literature (Chadwyck-Healey), the Arts and Humanities Citation Index (Thomson Reuters ISI), the Humanities Index (Wilson), Humanities International Complete (EBSCO), the International Bibliography of the Modern Language Association of America, and Scopus (Elsevier). The journal is affiliated with the Purdue University Press monograph series of Books in Comparative Cultural Studies. Contact: <clcweb@purdue.edu>

\section{Recommended Citation}

Ochiagha, Terri. "Fantasy Literature and the Misanthrope: A Review Article of New Work by Cottom and Zipes." CLCWeb: Comparative Literature and Culture 10.4 (2008): <https://doi.org/10.7771/1481-4374.1399>

This text has been double-blind peer reviewed by $2+1$ experts in the field.

The above text, published by Purdue University Press (CPurdue University, has been downloaded 1555 times as of 11/ $07 / 19$.

This document has been made available through Purdue e-Pubs, a service of the Purdue University Libraries. Please contact epubs@purdue.edu for additional information.

This is an Open Access journal. This means that it uses a funding model that does not charge readers or their institutions for access. Readers may freely read, download, copy, distribute, print, search, or link to the full texts of articles. This journal is covered under the CC BY-NC-ND license. 
PURDUE

UNIVERSITY PRESS <http://www.thepress.purdue.edu>

\section{CLCWeb: Comparative Literature and Culture}

ISSN 1481-4374 <http://docs.lib.purdue.edu/clcweb> Purdue University Press (CPurdue University

CLCWeb: Comparative Literature and Culture, the peer-reviewed, full-text, and open-access learned journal in the humanities and social sciences, publishes new scholarship following tenets of the discipline of comparative literature and the field of cultural studies designated as "comparative cultural studies." In addition to the publication of articles, the journal publishes review articles of scholarly books and publishes research material in its Library Series. Publications in the journal are indexed in the Annual Bibliography of English Language and Literature (Chadwyck-Healey), the Arts and Humanities Citation Index (Thomson Reuters ISI), the Humanities Index (Wilson), Humanities International Complete (EBSCO), the International Bibliography of the Modern Langua-ge Association of America, and Scopus (Elsevier). The journal is affiliated with the Purdue University Press monog-raph series of Books in Comparative Cultural Studies. Contact: <clcweb@purdue.edu>

Volume 10 Issue 4 (December 2008) Book Review Article 10 Terri Ochiagha,

"Fantasy Literature and the Misanthrope:

A Review Article of New Work by Cottom and Zipes" $<$ http://docs.lib.purdue.edu/clcweb/vol10/iss4/10>

Contents of CLCWeb: Comparative Literature and Culture 10.4 (2008) Thematic issue New Studies on the Fantastic in Literature Edited by Asunción López-Varela

<http://docs.lib.purdue.edu/clcweb/vol10/iss4/> 
Terri Ochiagha,

Fantasy Literature and the Misanthrope: A Review Article of New Work by Cottom and Zipes page 2 of 6 CLCWeb: Comparative Literature and Culture 10.4 (2008): <http://docs.lib.purdue.edu/clcweb/vol10/iss4/10> Thematic issue New Studies on the Fantastic in Literature. Ed. Asunción López-Varela

\section{Terri OCHIAGHA}

\section{Fantasy Literature and the Misanthrope: A Review Article of New Work by Cottom and Zipes}

We live in a world in which our very reality is a kaleidoscope of fantasies. There are bright colours, but in this age and time, we are overtaken by shadows. An overwhelming moral decadence, wars and diatribes in the name of deities, increasingly unattainable standards of living, and last but not the least the painful agony of the African continent and in those small and unprotected boats in which they set off in their quest for their own European fantasy, are just a few of the shadows in dire need of a beam of brighter colours. The sites of those fantasies many a time become the misanthrope's haven. Fantasy, ubiquitous construct of the imagination and the beyond, permeates the very humanity that we apparently dissociate from it. The boundaries of the human and the unhuman become blurred, and the ever-pervading question of its categorisations is never completely resolved.

Daniel Cottom's Unhuman Culture (Pennsylvania UP, 2006) and Jack Zipes's Why Fairy Tales Stick: the Evolution and Relevance of a Genre (Routledge, 2006) are devoted to some of the above issues, albeit with a different focus and in varied ways. But both address fantasy, and as such merge in their appreciation of one of our society's venerated tropes. In the preface and introduction to Unhuman Culture, Cottom puts us in perspective on what he deems "unhuman," a term he tries to dissociate from the cruelty and wickedness popularly associated with it. For Cottom, the unhuman means "Other" than human, marking "the borderlines of and contradictions within what is supposed to be human sovereignty; the unimaginable presumption that makes humanity imaginable; and most important, a perennial and perhaps inescapable tendency to underestimate art in humanity and to overestimate the humanity of art" ( $x$-xi). Misanthropy is upheld as a manifestation of the unhuman within humanity, an idea he develops throughout the book. In his introduction, where Chris Burden's photographic representations and Kafka's "Hunger Artist" and its intertextual relationship with such ancient forms as saints' lives become the image of the misanthrope, Cottom goes on to discuss how this figure has been understood by De Quincy, Burden, Kafka, and Fritz Lang and has become demonized by popular culture. The aesthetics of 9-11 and the fascination with its representation in the guise of films and pictures is facilitated through a suspension of belief; a creepy enjoyment of our very destruction and one of the unhuman motivations in art, for "it is precisely the effect of the unhuman that accounts for the notorious disjunction between our desire and the ability to draw a clear distinction between art and everyday life" (20). Misanthropy means turning away from mankind to attempt to fulfil one's humanity, and how that is done in photography, pictorial art, literature, philosophical works and sculptures is the aim of Unhuman Culture.

Chapter 1, "Crowning Presumptions," begins with a discussion of Napoleon's self-coronation, an act that makes him the supreme misanthrope as regards his presumption and self-invention, thus making him an exponent of the unhuman and Cottom explains how Napoleon's misanthropic act has been discussed by Foucault, Chateubriand, and Walter Scott and painted by Jacques Louis David. Cottom also discusses the literary birth of modernity in Marlowe's Tamburlaine and in The Tragical Historie of Doctor Faustus, both of which are considered aesthetic achievements similar to the self-coronation of Napoleon, examples of a misanthropy that stems from amour-propre. Cottom calls this narcissistic state a gothic quality, for its wish to transcend humanity. Besides the transcendental quality of Doctor Faustus, Cottom discusses the unhuman side of its anticipation of today's omnipresent contractual relations. He goes further to analyze Helen of Troy's apparition as an unhuman image in its fantastic component, fulfilling Faustus's and the audience's fantasies and quest for aesthetic pleasure, while underlining her destructiveness. "I Think: Therefore I am Heathcliff" is probably the most expository chapter of Cottom's book. He explores the Gothic novel and its protagonists as quintessential misanthropes, for thinking in the gothic novel leads to the recognition of one's existence in the misanthropic "Other," a trope that pervades such oeuvres as The Monk, The Italian, The Recess, Melmoth the Wanderer, and Wuthering Heights, which Cottom 
considers the most brilliant work in the gothic tradition. He points out that even the preface to the novel is unhuman, for Charlotte Brontë's condemnation and placement of her sister's identity in a family context is an exponent of the very misanthropy her sister created. Heathcliff is the unhuman agency, from his dubious origins and disruptive insertion to his devilish appearance. He (Heathcliff) is the quintessential misanthrope, a quality that leads Cathy to identify with him and of which the characteristic is a romantic love which is only consummated in ghostly visitations and the commingling of mortal remains, delving into the realm of art as distinct of that of life. Lockwood, who also claims to be a misanthrope, may reflect Brontë's mockery of modern readers, for he, along with Nelly does not think, employing the happenings at the Heights as a source of entertainment and gossip rather than a transcendental, or dare we say, religious experience. According to Cottom, Descarte's Meditations (1641) laid the foundation for the birth and proliferation of the Gothic novel, for it anticipated the tropes of the protagonists secluded by choice, their subsequent involuntary isolation and a growing mistrust on the evidence of their senses and on the fundamentals of Christian belief. The Meditations sought to prepare its readers for modernity by "entertaining the thought that their very selves might be works of art, the unhuman product of a misanthropic demon." (40)

The following chapter, "Immemorial," focuses on the journalistic nature of Francisco de Goya's work, for "only in the sign of the inartistic can we find an adequate response to the declination of observation into a horror so profound as to be immemorial" (56). The pictorial works analyzed, "That is what you were born for" and "This is worse," among those that Goya based on the Peninsular War, portray some of the merciless acts perpetrated by humans during war time. In engravings 66 through 80 of the series, Goya makes use of allegory, a technique that Cottom deems less effective because of its evasion of the unhuman and the integration of the horror into "images of symbolic wholes and universal themes" (62). Interestingly, animals are portrayed in a way reminiscent of La Fontaine and Aesop, and the problematics of this representation reside in the way the images deny their unhuman motivations and components, not seeking to transcend. Stendhal's The Charterhouse of Parma, Thackeray's Vanity Fair, and Tolstoy's War and Peace are equated with this approach, for "what they did not see, or at least did not choose to emphasize in their works, were immemorial heaps of particulars that can be comprehended historically and symbolically only at the cost of the very conception of art" (63).

Chapter 4 deals with iconoclasia as an exponent of misanthropy, focusing on Mary Richardson's disfiguration of Velázquez's "The Toilet of Venus." Cottom explores how iconoclasm confounds the distinction between image and person in a reverse creative act. The image, for those who appreciate it, signifies art, capital, and national identity in its being the property of a nation, furthermore, "It is the unhuman agency at work in art which enables us -- if only by comparing a painting to a living woman, as Richardson did -- to confront the violence that does its work in any given conception of humanity" (88). The following chapter is about the unhuman in machinery and pop culture. Marinetti's views are outlined, as are the cultural movements that embraced them, such as futurism, pop aesthetics and minimalism, in all of which "humanity in any particular conception is mortified by the unhuman aesthetic agency, and hence the challenging misanthropy, enacted through the approach to art" (92). These movements turn towards a mechanistic world, one in which humanity's marriage to technology results in the birth of the term "posthuman" as referring to a being as far removed from humanity as to be devoid of mortality. Cottom analyses the reactions and predictions of philosophers from the seventeenth century on the issue of 'mechanism' and technology as destroyers of constraints.

Chapter 6 is the most interesting and thought-provoking, for it merges with the seventh chapter of Why Fairy Tales Stick. Cottom analyses the reactions to George Segal's sculpture "Abraham and Isaac: In Memory of May 4, 1970," made as a homage to the four students shot down by guardsmen at Kent State University during a protest against the U.S. invasion of Cambodia. Abraham's sacrifice of Isaac has been discussed from its first apparition in the Bible, among many others, by Martin Luther and Kierkegaard, who asserted that the legend "prodded a collective guilty conscience, rather than providing a distraction or balm" (qtd. in Cottom 177), a reason why many 
have chosen to gloss over it, as Zipes argues. Cottom proceeds to an analysis of the two sculptures Segal erected based on the sacrifice of Isaac: the aforementioned "Abraham and Isaac" and "The Sacrifice of Isaac" (1973). The negative reaction of the university administration to the sculpture could have been due to the fact that what they wanted was "art in its popular modern understanding: art as a watered-down religion or, one might say, sanctified crime. What the faux folksy Segal gave them instead was art, and religion, in all their criminal power" (129). Chapter 7, "What is It Like to Be an Artwork?," takes its readers from Diderot's actor to Baudelaire's dandy, and to Orlan, the French artist who underwent surgery live on television to create an art oeuvre of sorts. Cottom analyses the body as an art object, arguing that being like a work of art is a simultaneous experience of abstraction of the very humanity that lies beneath the unhuman. The misanthropic value of being like a work of art resides in being the "Other." Cottom's conclusion restates his initial thesis: that "the excommunication of the misanthrope by society, or vice-versa, exposes the fallacy that continuity is founded on communication" (152). In particular, communication based on the repression of the "Other" and the wilful manipulation of the self, we venture to add.

A follow up to his Fairy Tales and the Art of Subversion: The Classical Genre for Children and the Process of Civilization (1983), Jack Zipes's Why Fairy Tales Stick updates his earlier approach through his use of relevance theory, social Darwinism, evolutionary psychology, and linguistics in order to explain the evolution of the fairy tale from its oral mode to its permanence in popular imagery. The first chapter, "Toward a Theory of the Fairy Tale as Literary Genre," is a wonderful introduction to the genre with Zipes's detailed explanations of its evolution. Starting from their adaptation originated in the oral tradition to their institution as genre in the seventeenth century, fairy tales, Zipes argues, have been constituted as memes, or informational patterns contained in the human brain and transmitted through public production. Although there is subjective criteria as to why such memes are relevant, many will be produced because of their relevance to the sociocultural context and because they are "vital to the survival of a community and the preservation of its values and beliefs" (11). Zipes goes through the theorizations of genre from the viewpoints of Bakhtin, Todorov, and Stock to arrive at the concept of généricité, the term coined by Jean Michel Adam and Ute Heidmann, and that Zipes considers of relevant for his study. He maintains that "we have been attracted to fairy tales because they are survival stories with hope" (27), which he exemplifies by his analysis of "Little Red Riding Hood," reviewing the arguments expounded in his Trials and Tribulations of Little Red Riding Hood (1993) and going through the origins and different versions of the tale, from Perrault to the Brothers Grimm. All in all, his contention is that "If there are really such things as memes -- and I am convinced there are -- and if memes can influence us and be changed as our behaviour is transformed, it is important that we take the theory of memes and fairy tales themselves more seriously. As we know, tales do not speak to us, they inhabit us and become relevant in our struggles to resolve conflicts that endanger our happiness" (39).

In Chapter 2 Zipes delves further into the evolution and dissemination of fairy tales. Tracing their oral sources to the time when people told "all kinds of 'fantastic' tales about gods, animals, catastrophes, wars, heroic deeds, rituals, customs and daily incidents" (44), many of which displayed a sense of wonder and transgression, Zipes tells us how they were viewed with suspicion by the ruling clerical and educated classes, who proceeded to codify them for their own interests, for "wonder tales and fairy tales were declared sacrilegious, heretical, dangerous and untruthful" (53), just as Cottom's misanthropes were. Oriental tales seeped into the fairy tale imaginary, and Zipes gives us traces the evolution of the genre in France, through Staporola and Galland's works, who suffused them with Oriental lore abetted by the power of salon culture. Zipes moves on to the evolution of the genre in Germany and focuses on the role of the Brothers Grimm, the genesis of their association with the fairy tale, and their intention on creating tales that every German, irrespective of age, could relate to. The fact that fairy tales remained suspect until 1820 led to the purgation of all the "inappropriate" constituents while maintaining the fantastic elements. Zipes also chronicles Hans Christian Andersen's role as the most popular writer of fairy tales in the nineteenth century, moving on the beginnings of the twentieth century. 
Terri Ochiagha,

Fantasy Literature and the Misanthrope: A Review Article of New Work by Cottom and Zipes page 5 of 6 CLCWeb: Comparative Literature and Culture 10.4 (2008): <http://docs.lib.purdue.edu/clcweb/vol10/iss4/10> Thematic issue New Studies on the Fantastic in Literature. Ed. Asunción López-Varela

Chapter 3, "Once Upon a Time in the Future: The Relevance of Fairy Tales" begins with a summary of the points raised in the earlier chapters. Zipes maintains that "The appeal of fairy tales still has a great deal to do with utopian transformation and the desire for a better life, and the manner in which we make it relevant in our mental representations will be in reaction to the outside stimuli and to moral codes instituted by hegemonic groups within a respective society. The more social relations make us discontent and feel as though we were objects alienated from our own communities the more we seek a haven in mental projections of other worlds" (106). In other words, fairy tales are the misanthrope's haven. This and the subsequent chapters are devoted to case studies of several tales, basing their inclusion in each chapter on a thematic categorization: chapter 3 deals with "Cinderella," the following chapter with "Snow White," "Beauty and the Beast," "Mulan," and "X-men" while the fifth and sixth chapters focus on "Blue-beard" and "Hansel and Gretel," respectively. While all the preceding chapters delve into the problematics of the theme pervading each of the tales, they contextualise the texts and discuss variations of the same. Chapter 6 is very informative in its theorization of the role of translation in the reinterpretation and perpetuation of the fairy tale, and Zipes's statement that versions that do not re-examine the texts are wont to "misinterpret the past and keep readers in a state of historical oblivion, even if the illustrators set their images in the past." (203)

Chapter 7 begins with a stimulating discussion of the formation of the canon under the watchful eyes of religious, educational, and political institutions. Zipes discusses the reasons why this very canon should be questioned and problematized, touching on how minds are subverted through the appropriation and manipulation of fairy tales by mass media and that ambivalent construct called "tradition." He warns us that "If we do not question and undo dominant storytelling, we risk not only losing the imaginative vision, but we also place our children at risk, as we already have. Their survival depends on our continual engagement with cultural tradition, opening them up, and opening us in the process" (243). To demonstrate an example of this subversion of minds, he zeroes in on the legendary Biblical story of Abraham and Isaac of Christian, Jewish, and Muslim legacy, and that has been used to rationalize all sorts of horrific acts. Zipes refers Feiler's and Kierkegaard's opposing views on the myth and to the vast amount of exegesis, apocryphal stories, and translated versions of the story. Feiler's tacit silence on the element of child abuse and infanticide parallels the refusal of the Kent State University authorities to accept Segal's sculpture as discussed by Cottom and it demonstrates "vividly how tradition represses (or inadvertently reveals) how we bake and eat our children, or if we keep them alive, how we beat stories into them that will make them willing subjects of forces to whom they grant control over their destinies" (253).

Both works discussed in this review article, in spite of the differences in scope, style, and content, merge in their assertion of fantasy as the misanthrope's haven: that which they inhabit, or that in which they become in the very act of fantasizing. Unhuman Culture will be of interest to scholars and undergraduates of cultural studies in general, and the fantastic and the gothic in particular, although the book's philosophical nature might make it less accessible to a larger audience. Why Fairy Tales Stick focuses on literary texts, while referencing other types of the fairy tale such as operas and films. A reservation on my part, however, is that while he asserts that "many of the so-called Western fairy tales received impulses from and owe their germination to tales that emanated from the ancient Orient or Africa" (xiv), Zipes does not explain how this happened, although he mentions that Somalians cultivated their tales through oral transmission and lists Egyptian tales as a source of inspiration to Western fairy tales. With his extensive scholarship, it is to be hoped that Zipes will research and publish some work more inclusive of non-Western traditions -- Oriental and African in particular -- in the future and that his readers will take due note of the lacunae Western scholarship tends to gloss over.

Reviewer's profile: Terri Ochiagha is completing her doctoral dissertation on African literature at Complutense University Madrid, entitled Images and Reflections of European Others in Nigerian Narratives. Her interests in research include the image of the European in African prose, the literary representation of colonial education, 
Terri Ochiagha,

Fantasy Literature and the Misanthrope: A Review Article of New Work by Cottom and Zipes

page 6 of 6

CLCWeb: Comparative Literature and Culture 10.4 (2008): <http://docs.lib.purdue.edu/clcweb/vol10/iss4/10> Thematic issue New Studies on the Fantastic in Literature. Ed. Asunción López-Varela

the supernatural in English and African fiction, and the literary ambience of Government College, Umuahia. Email: <terriochiagha@estumail.filol.ucm> 